\title{
The role of phytochelatins in arsenic tolerance in the hyperaccumulator Pteris vittata
}

\author{
F. J. Zhao ${ }^{1}$, J. R. Wang ${ }^{1}$, J. H. A. Barker ${ }^{2}$, H. Schat ${ }^{3}$, P. M. Bleeker ${ }^{3}$ and S. P. McGrath ${ }^{1}$ \\ ${ }^{1}$ Agriculture and Environment Division, Rothamsted Research, Harpenden, Hertfordshire AL5 2JQ, UK; ${ }^{2}$ Crop Performance and Improvement Division, Long \\ Ashton Research Station, Long Ashton, Bristol, BS41 9AF, UK; and ${ }^{3}$ Department of Ecology and Physiology of Plants, Faculty of Earth and Life Sciences, Vrije \\ Universiteit, De Boelelaan 1085, 1081 HV Amsterdam, The Netherlands
}

Author for correspondence:

F. J. Zhao

Tel: +441582763133

Fax: +441582760981

Email: Fangiie.Zhao@bbsrc.ac.uk;

Received: 9 January 2003

Accepted: 11 March 2003

doi: 10.1046/j.1469-8137.2003.00784.x

\section{Summary}

- Pteris vittata was the first identified arsenic (As) hyperaccumulator. Here we investigated whether phytochelatins (PCs) are involved in the hypertolerance of arsenic by $P$. vittata.

- P. vittata was exposed to $0-500 \mu \mathrm{M}$ arsenate for $5 \mathrm{~d}$, or to $50 \mu \mathrm{m}$ arsenate for 0-7 d. In addition, L-buthionine-sulphoximine (BSO), an inhibitor of $\gamma$-glutamylcysteine synthetase, was used in combination with different arsenate exposures. The relationships between As accumulation and the concentrations of PCs and glutathione (GSH) were examined.

- $P C$ synthesis was induced upon exposure to arsenate in $P$. vittata, with only $P C_{2}$ detected in the plant. The As concentration correlated significantly with $\mathrm{PC}_{2}$ concentration in both roots and shoots, but not with GSH. The molar ratio of PC-SH to As was C. 0.09 and 0.03 for shoots and roots, respectively, suggesting that only a small proportion (1-3\%) of the As in P. vittata can be complexed with PCs. In the presence of arsenate, addition of $\mathrm{BSO}$ decreased $\mathrm{PC}_{2}$ concentrations in roots and shoots by $89-96 \%$ and $30-33 \%$, respectively. BSO alone was found to inhibit root growth of $P$. vittata markedly.

- The results suggest that PCs play a limited role in the hypertolerance of As in P. vittata.

Key words: Pteris vittata, arsenic (As), hyperaccumulation, phytochelatins, tolerance.

(C) New Phytologist (2003) 159: 403-410

\section{Introduction}

The brake fern Pteris vittata is the first identified arsenic (As) hyperaccumulator (Ma et al., 2001). It can accumulate $>20000 \mathrm{mg} \mathrm{As} \mathrm{kg}^{-1}$ in the shoot (frond) dry weight (d. wt). Furthermore, the bioconcentration factor, defined as the ratio of shoot As concentration to soil As concentration, was greater than 10. P. vittata is also hypertolerant to As, with a toxicity

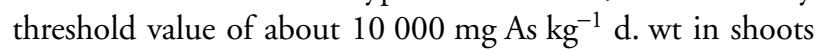
(Tu \& Ma, 2002; Wang et al., 2002). This compares with

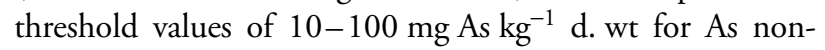
tolerant plants (Kabata-Pendias \& Pendias, 1992). More recently, several other fern species in the order Pteridales have been identified to be As hyperaccumulators (Visoottiviseth et al., 2002; Zhao et al., 2002). These plants may have potential for phytoremediation of As-contaminated soils or waters. Moreover, these plants offer an interesting model for studying As metabolism in plants.

Inorganic As species are generally highly phytotoxic. Arsenate is a phosphate analogue and can disrupt phosphate metabolism, whereas arsenite reacts with sulfydryl groups of enzymes and tissue proteins, leading to inhibition of cellular function and death (Meharg \& Hartley-Whitaker, 2002). In As nonhyperaccumulating plant species, two mechanisms of As tolerance have been identified. First, tolerant plants have a decreased uptake of arsenate due to a suppression of the highaffinity phosphate uptake system (Meharg \& Macnair, 1991, 1992; Meharg \& Hartley-Whitaker, 2002). Second, arsenate 
taken up by plants is detoxified through reduction to arsenite, which is subsequently complexed with thiols, particularly phytochelatins (PCs). There are several lines of evidence for an important role of PCs in As tolerance. First, exposure to As induces a large response in the synthesis and accumulation of PCs in a number of plant species (Grill et al., 1987; Maitani et al., 1996; Sneller et al., 1999; Schmöger et al., 2000). Second, As-tolerant populations of Holcus lanatus were found to accumulate more PCs than nontolerant ones under the same degree of As stress (Hartley-Whitaker et al., 2001; HartleyWhitaker et al., 2002). Third, inhibition of PC synthesis by a treatment with L-buthionine-sulphoxime (BSO), a potent inhibitor of $\gamma$-glutamylcysteine synthetase, leads to hypersensitivity to As in both As nontolerant and tolerant plants (Schmöger et al., 2000; Hartley-Whitaker et al., 2002; Schat et al., 2002). Fourth, an Arabidopsis thaliana mutant lacking functional PC synthase was significantly more sensitive to As toxicity than the wild type (Ha et al., 1999). Fifth, X-ray absorption spectroscopy reveals that the majority of As in the leaves of Brassica juncea and A. thaliana was coordinated to thiols (Pickering et al., 2000; Dhankher et al., 2002). Furthermore, intact PCs-As complexes have been isolated from plant tissues (Sneller et al., 1999; Schmöger et al., 2000).

The tolerance to As in P. vittata is at least an order of magnitude greater than in As nonhyperaccumulating plants. The mechanisms of As hypertolerance in P. vittata have not been elucidated. Arsenic extracted from the shoots of $P$. vittata appeared to be present mainly as inorganic arsenite (Francesconi et al., 2002; Wang et al., 2002). However, there is a possibility that the extraction procedure and subsequent speciation analysis may not preserve thiol-As complexes. Thus, the objective of this study was to investigate whether PCs are involved in the hypertolerance to As in the hyperaccumulator $P$. vittata.

\section{Materials and Methods}

\section{Plant culture}

Spores of P. vittata L. (produced from adult plants of the Florida accession, kindly provided initially by Dr Lena Ma, University of Florida, Gainesville, FL, USA) were germinated on moist potting compost. At the two-frond stage, sporelings were transplanted individually into $8-\mathrm{cm}$ pots containing a general-purpose potting compost, and allowed to grow to the three-four frond stage. Plant roots were then washed carefully with tap water to remove adhering compost and transferred to $250-\mathrm{ml}$ pots (one plant per pot) containing a nutrient solution, which was a modified Hoagland solution with $1 / 2$ strength major nutrients and full strength micronutrients (except that Fe was supplied as Fe-EDTA at $100 \mu \mathrm{M}$ ) (Hewitt, 1966). Solution $\mathrm{pH}$ was buffered at around 6.0 using $5 \mathrm{~mm}$ MES (2-morpholino-ethanesulphonic acid). The nutrient solution was aerated continuously and renewed every $5 \mathrm{~d}$. Plants were grown in the hydroponic culture for $3 \mathrm{wk}$ before experiments started. The hydroponic culture and all experiments were conducted inside a controlled environment growth chamber with the following conditions: $16 \mathrm{~h}$ light period with a light intensity of $350 \mu \mathrm{mol} \mathrm{m}^{-2} \mathrm{~s}^{-1}, 25^{\circ} \mathrm{C} / 20^{\circ} \mathrm{C}$ day/night temperatures and $60 \%$ relative humidity.

\section{Experiment 1}

P. vittata plants were exposed to increasing concentrations of arsenate $(0,10,50,100$ and $500 \mu \mathrm{M})$ for $5 \mathrm{~d}$. Arsenate was supplied as $\mathrm{Na}_{2} \mathrm{HAsO}_{4}$, and the composition of nutrients was the same as in the preculture. Each treatment was replicated three-fold. After $5 \mathrm{~d}$ of exposure, plant roots and shoots were rinsed thoroughly with deionized water, blotted dry and separated. Roots and shoots were frozen in liquid nitrogen and freeze-dried at $-60^{\circ} \mathrm{C}$ for $3 \mathrm{~d}$. Samples were ground and stored in vials at $-80^{\circ} \mathrm{C}$ until analysis.

\section{Experiment 2}

P. vittata plants were exposed to $50 \mu \mathrm{M}$ arsenate $\left(\mathrm{Na}_{2} \mathrm{HAsO}_{4}\right)$ for $0,1,3$ and $7 \mathrm{~d}$. This concentration was chosen because it was not toxic to $P$. vittata in preliminary experiments. The composition of nutrients was the same as in the preculture. On each sampling occasion, plants from three replicate pots were harvested and treated as described above.

\section{Experiment 3}

This experiment was conducted to investigate the effect of L-buthionine-sulphoximine (BSO) and arsenate exposure on root growth and PC synthesis. After 3 wk of preculture under hydroponic conditions, plants in 18 pots were treated with $500 \mu \mathrm{M}$ BSO for $5 \mathrm{~d}$. Another group of 18 plants was not treated with BSO. Thereafter, plants were exposed to 0,500 and $1000 \mu \mathrm{M}$ arsenate $\left(\mathrm{Na}_{2} \mathrm{HAsO}_{4}\right)$, with or without $500 \mu \mathrm{M}$ $\mathrm{BSO}$, for a further $5 \mathrm{~d}$. Each As and BSO treatment was replicated in six pots. Root elongation after $5 \mathrm{~d}$ exposure was measured in three pots of each treatment using the charcoal staining method (Schat \& Ten Bookum, 1992). The remaining three pots for each treatment, unstained with charcoal, were used for the analysis of As and PCs. The plants were harvested and treated as described for Experiment 1.

\section{Analysis}

Ground plant materials were digested with a mixture of $\mathrm{HNO}_{3} /$ $\mathrm{HClO}_{4}(85 / 15, \mathrm{v} / \mathrm{v})$ and the concentrations of As were determined using inductively coupled plasma-atomic emission spectroscopy (ICP-AES, Fisons-ARL Accuris, Ecublens, Switzerland). Blanks and internal standards were included for quality assurance.

Freeze-dried plant material $(20 \mathrm{mg})$ from Experiment 3 was extracted with $5 \mathrm{ml} 30 \mathrm{~mm}$ ammonium phosphate buffer at 
New

Phytologist

$\mathrm{pH} 5.6$ in a sonication bath for $30 \mathrm{~min}$. The suspension was centrifuged and filtered through a Whatman No. 42 filter paper. As(III) and As(V) were determined in the extracts using automated hydride-generation atomic absorption spectrometry (Glaubig \& Goldberg, 1988).

Extraction and analysis of PCs and glutathione (GSH) were performed using a slightly modified method described by Sneller et al. (2000). Freeze-dried plant material $(10 \mathrm{mg})$ was ground in a mortar and pestle in $2 \mathrm{ml} 6.3 \mathrm{~mm}$ DTPA (diethylenetriaminepentaacetic acid) with $0.1 \%$ (v/v) trifluoroacetic acid at $4^{\circ} \mathrm{C}$. $N$-acetyl cysteine was added during grinding as an internal standard. The contents were centrifuged at $13000 \mathrm{~g}$ for $10 \mathrm{~min}$ at $4^{\circ} \mathrm{C}$ and the supernatant filtered through a Costar Spin-X centrifuge tube with a $0.22-\mu \mathrm{m}$ nylon filter. The thiols in the extract $(250 \mu \mathrm{l})$ were derivatized with $10 \mu \mathrm{l} 25 \mathrm{~mm}$ monobromobimane, together with $450 \mu \mathrm{l}$ $200 \mathrm{~mm}$ 4-(2-hydroxyethyl)-piperazine-1-propanesulphonic acid buffer at $\mathrm{pH} 8.2$ and $6.3 \mathrm{~mm}$ DTPA. Derivatization was carried out at $45^{\circ} \mathrm{C}$ for $30 \mathrm{~min}$. The reaction was stopped by the addition of $300 \mu \mathrm{l}$ of $1 \mathrm{M}$ methanesulphonic acid. GSH and PCs were separated on two tandemly arranged Nova-Pak $\mathrm{C}_{18}$ columns $(6 \mathrm{~nm}, 4 \mu \mathrm{m}, 3.9 \times 150 \mathrm{~mm}$, Waters, Milford, MA, USA) at $37^{\circ} \mathrm{C}$, using a slightly concave gradient of $12 \%$ to $25 \%(\mathrm{v} / \mathrm{v})$ methanol for $15 \mathrm{~min}$ and then a linear gradient from $25 \%$ to $50 \%$ (v/v) methanol from 15 to 40 min. Fluorescence was monitored using a Waters 474 fluorescence detector. HPLC peaks were identified by mixing some of the P. vittata samples with a Silene vulgaris sample, which has a known PC composition established previously through amino acid analysis of the purified peak fraction. Reduced GSH was used as an external standard. PC concentrations were calculated as $\mu \mathrm{mol}$ GSH equivalent $\mathrm{g}^{-1} \mathrm{~d}$. wt and corrected for derivatization efficiency (Sneller et al., 2000).

Analysis of variance was performed on all data. Least significant difference was used to compare treatment means.

\section{Results}

\section{Experiment 1: effects of arsenate exposure concentration}

There were no signs of phytotoxicity in P. vittata after $5 \mathrm{~d}$ exposure to arsenate up to $500 \mu \mathrm{M}$. The concentrations of As in both roots and shoots increased significantly $(P<0.05)$ with increasing As concentration in the nutrient solution (Fig. 1a). In the 100 and $500 \mu \mathrm{M}$ As treatments, the concentration of As in the shoots exceeded $1000 \mu \mathrm{g} \mathrm{g}^{-1} \mathrm{~d}$. wt $\left(13.3 \mu \mathrm{mol} \mathrm{g}^{-1}\right)$, which is the threshold value used to define As hyperaccumulation. Furthermore, the concentrations of As in the shoots were greater than those in the roots, indicating an efficient root to shoot translocation.

In the control treatment (no As), the concentrations of PCs in both roots and shoots were negligible. Arsenate exposure induced PC synthesis in both roots and shoots of $P$. vittata

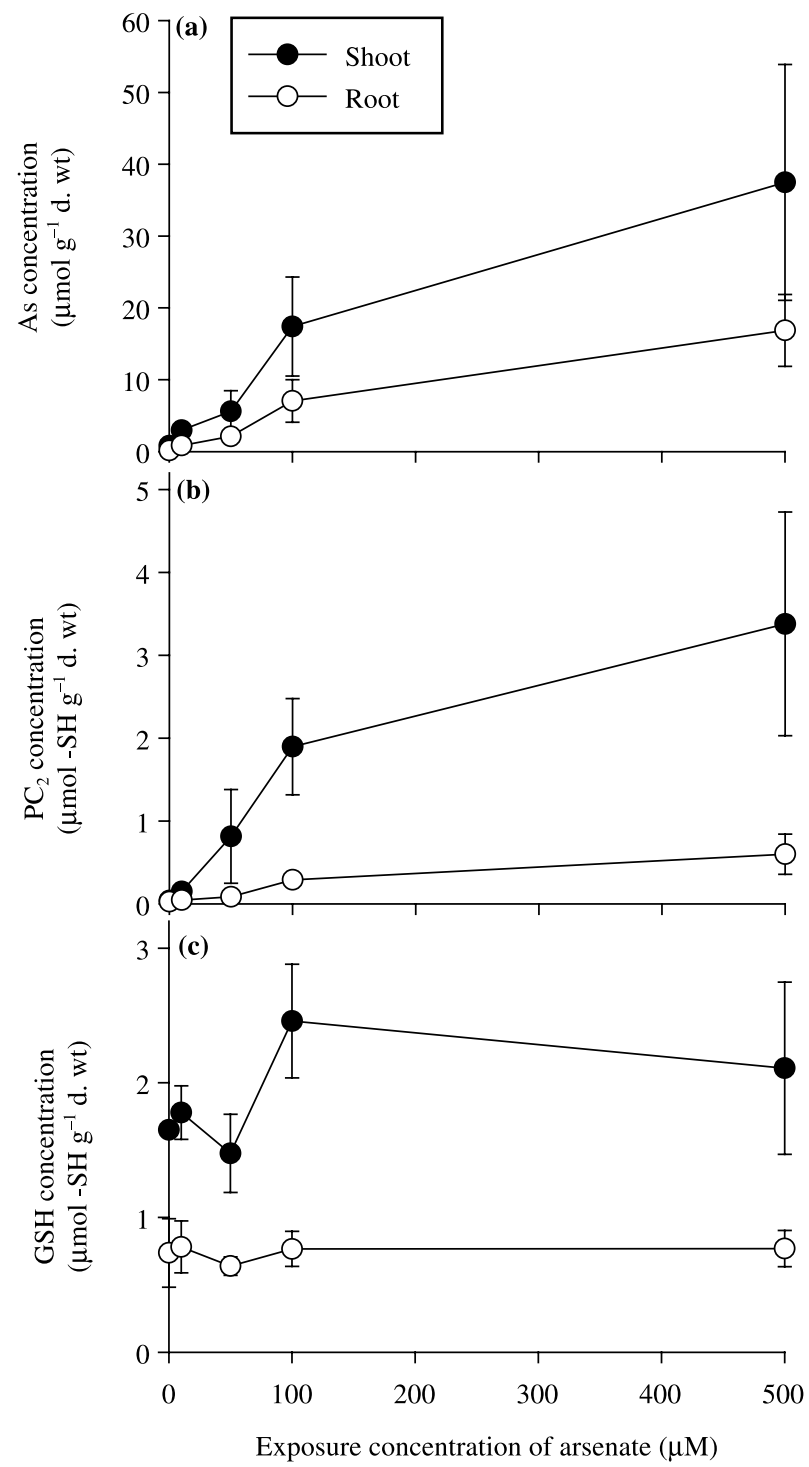

Fig. 1 Effects of arsenate exposure for $5 \mathrm{~d}$ on the concentrations of As (a), PCs (b) and GSH (c) in Pteris vittata. Bars represent \pm SEs.

$(P<0.05$; Fig. $1 b)$. Only $\mathrm{PC}_{2}$ was detected in the plants. In the HPLC chromatograph (result not shown), $\mathrm{PC}_{2}$ in $P$. vittata coeluted exactly with the $S$. vulgaris $\mathrm{PC}_{2}$. Since the latter is a glycine-PC (Sneller et al., 2000), this result infers that the P. vittata $\mathrm{PCs}$ possess a glycine $\mathrm{C}$-terminal. The concentrations of $\mathrm{PC}_{2}$ were 3-10 fold higher in the shoots than in the roots. The concentrations of glutathione were not significantly $(P=0.42$ and 0.97 for shoot and root GSH, respectively) influenced by the As treatments (Fig. 1c).

\section{Experiment 2: effects of arsenate exposure time}

In this experiment, $P$. vittata was exposed to $50 \mu \mathrm{M}$ arsenate for up to $7 \mathrm{~d}$. Arsenic accumulation by $P$. vittata increased with exposure time (Fig. 2a). By day 3, the concentration of As in the shoots was more than double that in the roots. The 


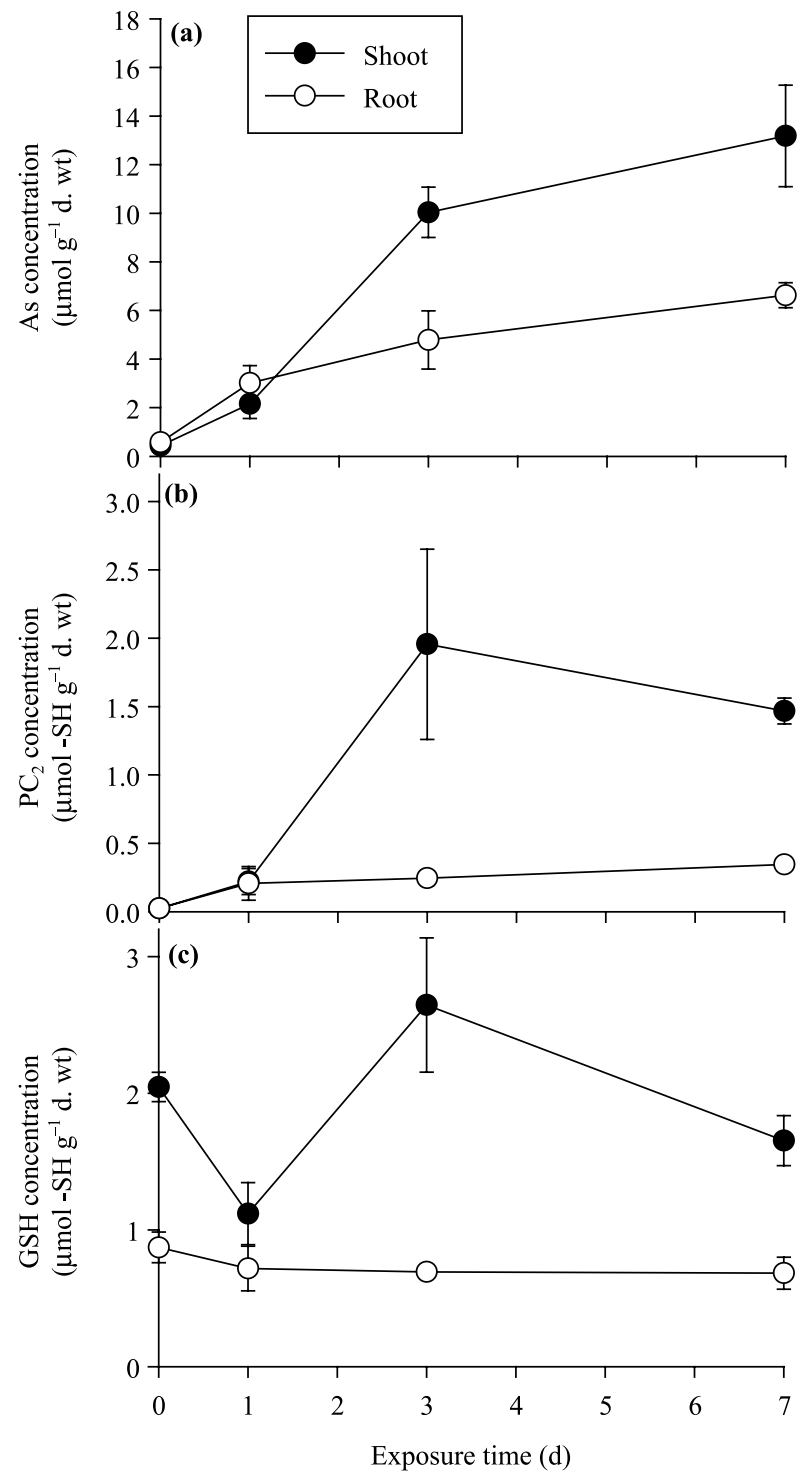

Fig. 2 Effects of arsenate exposure time on the concentrations of As (a), PCs (b) and GSH (c) in Pteris vittata. Bars represent \pm SEs.

synthesis of $\mathrm{PC}_{2}$ was induced by As exposure (Fig. 2b). In the shoots, $\mathrm{PC}_{2}$ concentration appeared to peak on day 3 and remained at a similar concentration on day 7 . The concentration of $\mathrm{PC}_{2}$ in the roots was much smaller than that in the shoots. The concentration of GSH in the roots was not significantly $(P=0.64)$ influenced by the duration of As exposure (Fig. 2c). Shoot GSH level appeared to decrease during the first day of arsenate exposure and then recovered by day $3(P=0.048)$.

Fig. 3 shows the relationships between As, PC and GSH concentrations in roots and shoots of $P$. vittata. The data represent individual replicates for all treatments in Experiments 1 and 2 . In both roots and shoots, PC concentration correlated positively and significantly $(P<0.001)$ with As concentration (Fig. 3a). The slopes, which represent the molar ratio of the PC-SH to As in the plants, were 0.09 and 0.03 for

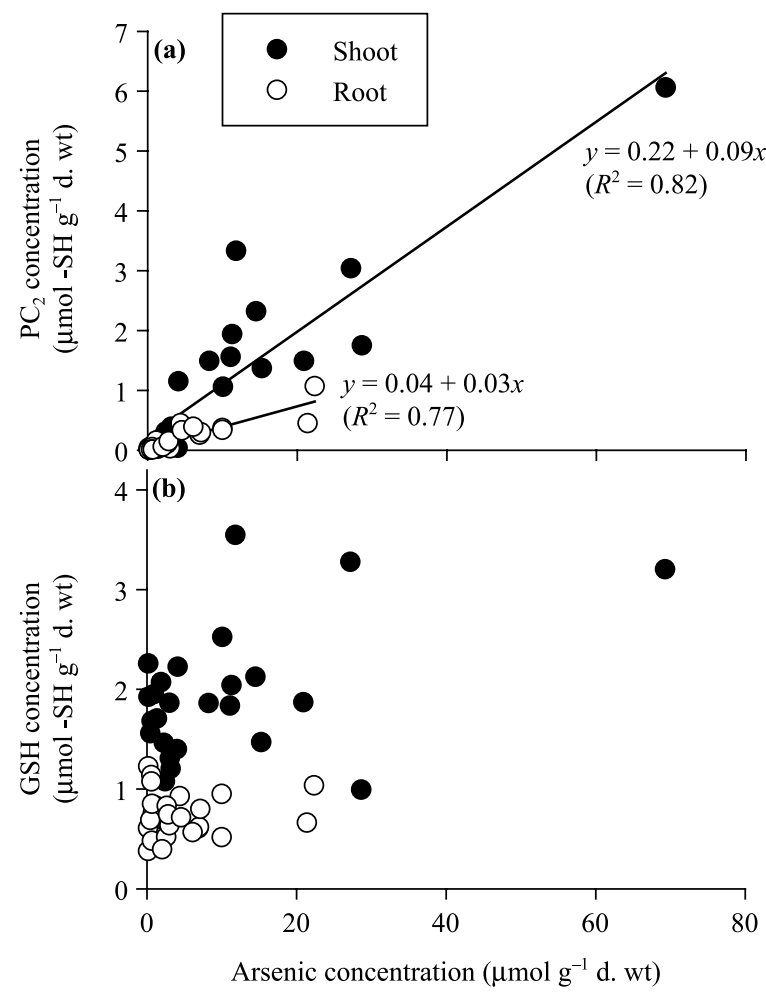

Fig. 3 Relationships between the concentrations of As and PCs (a) and GSH (b) in Pteris vittata. Data are from Experiments 1 and 2.

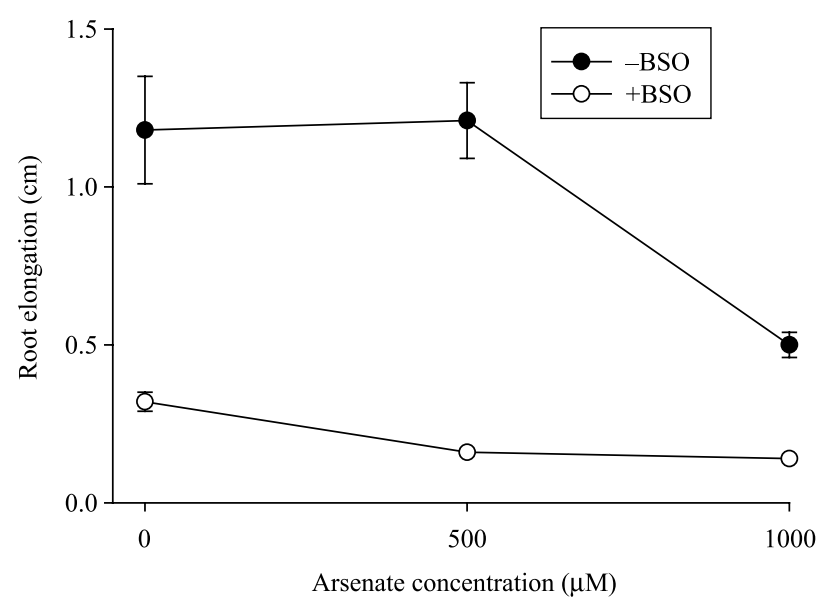

Fig. 4 Effects of L-buthionine-sulphoximine (BSO) and arsenate exposure on root elongation in Pteris vittata. Bars represent \pm SEs.

the shoot and root tissues, respectively. By contrast to PC, there was no significant correlation between GSH and As concentrations (Fig. 3b).

\section{Experiment 3: effects of BSO}

Without $\mathrm{BSO}$ in the nutrient solution, root elongation during the 5-d treatment period was not significantly affected by $500 \mu \mathrm{M}$ arsenate, but was inhibited by $58 \%$ when $1000 \mu \mathrm{M}$ arsenate was present (Fig. 4). Addition of $500 \mu \mathrm{M}$ 
New

Phytologist

Fig. 5 Effects of arsenate and L-buthioninesulphoximine (BSO) treatments on the concentrations of As, GSH and PCs in the roots $(a-c)$ and shoots $(d-f)$ of Pteris vittata. Bars represent \pm SEs.
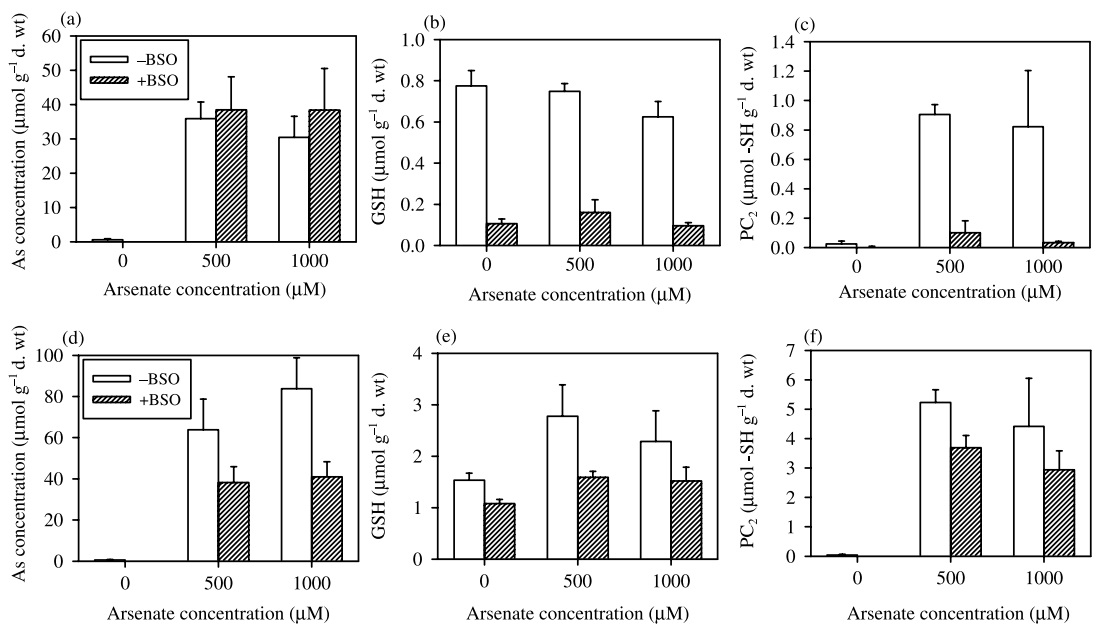

BSO inhibited root elongation by $73 \%$ in the absence of arsenate. In the presence of BSO, addition of $500 \mu \mathrm{M}$ arsenate decreased root elongation by $50 \%$, suggesting the possibility of an increased sensitivity of $P$. vittata to As toxicity. However, the severe effect of BSO on root elongation masked the effect of arsenate exposure. Phytotoxicity symptoms appeared in the shoots in the $1000 \mu \mathrm{M}$ arsenate treatment, but the degree of phytotoxicity appeared similar with or without BSO.

Fig. 5 shows the concentrations of $\mathrm{As}, \mathrm{GSH}$ and $\mathrm{PC}_{2}$ in the roots and shoots of P. vittata in Experiment 3. The BSO treatment decreased shoot As concentration significantly $(P<0.05$; Fig. $5 \mathrm{~d})$, but had no significant effect on root As concentration (Fig. 5a). The effect of BSO on the As accumulation in shoots may be a result of the inhibitory effect of BSO on root growth. Addition of BSO decreased the concentrations of GSH in the roots by $83 \%(P<0.001$, Fig. 5 b). The BSO treatment also decreased the concentration of $\mathrm{PC}_{2}$ in the roots by $89-96 \%$ in the + As treatments $(P<0.001$; Fig. 5c). In comparison, the effects of $\mathrm{BSO}$ on the concentrations of GSH and $\mathrm{PC}_{2}$ in the shoots were much smaller (30-43\% reduction; $P<0.05$ and $P=0.13$ for GSH and $\mathrm{PC}_{2}$, respectively; Fig. 5e,f).

The root and shoot tissues from the As-exposed treatments were extracted with ammonium phosphate buffer at $\mathrm{pH} 5.7$ for the determination of As speciation. This extraction procedure was found to extract on average $98 \%$ of the total As. In the shoot extracts, As(III) accounted for $85-90 \%$ of the total As, with the remaining proportion as As $(\mathrm{V})$ (Table 1). In the roots, $\mathrm{As}(\mathrm{V})$ was the predominant species, accounting for 81 $97 \%$ of the total As in the extracts, whilst As(III) represented only $3-19 \%$. The BSO treatment decreased the proportion of As in the roots present as As(III) significantly $(P<0.001)$, but had no significant effect on As speciation in the shoots.

\section{Discussion}

The results from all three experiments confirm the extraordinary ability of $P$. vittata to take up and transport As to the shoots. Wang et al. (2002) showed that arsenate is taken up via the phosphate uptake systems in $P$. vittata, similarly to As nonaccumulating plants (Asher \& Reay, 1979; Ullrich-Eberius et al., 1989; Meharg \& Hartley-Whitaker, 2002). Clearly, P. vittata does not employ the As resistance mechanism commonly found in many As tolerant plants, that is a decreased arsenate uptake through suppressed high affinity phosphate transporters (Meharg \& Macnair, 1992; Meharg \& Hartley-Whitaker, 2002). In agreement with previous studies (Ma et al., 2001; Francesconi et al., 2002;

Table 1 Arsenic speciation in the shoots and roots of Pteris vittata from Experiment 3

\begin{tabular}{|c|c|c|c|c|c|c|c|}
\hline \multirow[b]{2}{*}{$\begin{array}{l}\text { As treatment } \\
(\mu M)\end{array}$} & \multirow[b]{2}{*}{$\begin{array}{l}\text { BSO treatment } \\
(\mu \mathrm{M})\end{array}$} & \multicolumn{3}{|l|}{ Shoot } & \multicolumn{3}{|l|}{ Root } \\
\hline & & $\begin{array}{l}\text { Total As } \\
\left(\mu \mathrm{mol} \mathrm{g}{ }^{-1} \text { d. } w \mathrm{t}\right)^{*}\end{array}$ & $\%$ as $\mathrm{As}(\mathrm{III})$ & $\begin{array}{l}\% \text { as } \\
\text { As(V) }\end{array}$ & $\begin{array}{l}\text { Total As } \\
\left(\mu \mathrm{mol} \mathrm{g}{ }^{-1} \text { d. } w \mathrm{t}\right)^{*}\end{array}$ & $\%$ as $\mathrm{As}(\mathrm{III})$ & $\begin{array}{l}\% \text { as } \\
\operatorname{As}(\mathrm{V})\end{array}$ \\
\hline \multirow[t]{2}{*}{500} & 0 & $69.1 \pm 14.5$ & $84.7 \pm 2.5$ & $15.3 \pm 2.5$ & $36.8 \pm 4.9$ & $13.0 \pm 2.0$ & $87.0 \pm 2.0$ \\
\hline & 500 & $40.3 \pm 8.8$ & $89.7 \pm 1.0$ & $10.3 \pm 1.0$ & $32.8 \pm 7.4$ & $4.2 \pm 0.7$ & $95.8 \pm 0.7$ \\
\hline \multirow[t]{2}{*}{1000} & 0 & $71.6 \pm 16.9$ & $89.9 \pm 3.3$ & $10.1 \pm 3.3$ & $34.2 \pm 6.1$ & $18.6 \pm 3.4$ & $81.4 \pm 3.4$ \\
\hline & 500 & $40.0 \pm 5.1$ & $90.5 \pm 2.7$ & $9.5 \pm 2.7$ & $39.1 \pm 12.0$ & $3.2 \pm 1.4$ & $96.8 \pm 1.4$ \\
\hline
\end{tabular}

* Total As concentration extracted with ammonium phosphate buffer and determined by hydride-generation atomic absorption spectrometry (HG-AAS). Values are means \pm SEs. BSO, L-buthionine-sulphoximine. 
Wang et al., 2002), we found that As(III) was the predominant species of As in the shoots of $P$. vittata, whereas in the roots As was present mainly as As(V). Whether As(III) was present as aqueous arsenite species or as complexed arsenite cannot be determined by the speciation method used in this study. However, evidence from studies using more sophisticated methodologies, for example HPLC-ICP-MS and $\mathrm{X}$-ray absorption spectroscopy, indicates that As(III) in the leaves of $P$. vittata is present primarily as aqueous arsenite species (Wang et al., 2002; Webb et al., 2003). The difference between roots and shoots in As speciation suggests that leaves may be the main location of arsenate reduction. Reduction of arsenate to arsenite is mediated by the arsenate reductase enzyme in a glutathione-dependent reaction in both Escherichia coli (Gladysheva et al., 1994) and Saccharomyces cerevisiae (Mukhopadhyay et al., 2000). A similar mechanism may operate in $P$. vittata, although this has not been established. Higher concentrations of GSH were found in the shoots of P. vittata than in the roots (Figs 1, 2, 3 and 5), which would favour arsenate reduction in the leaves. The reduction of arsenate to arsenite in roots appeared to be inhibited by the BSO treatment (Table 1), probably as a result of a marked decrease in the concentration of GSH in the BSO-treated roots.

Arsenite has a high affinity to thiols and complexation of arsenite by PCs may be expected. Exposure to As has been shown to elicit synthesis and accumulation of PCs in a number of plant species that are As nonhyperaccumulators (Grill et al., 1987; Maitani et al., 1996; Sneller et al., 1999; Schmöger et al., 2000; Hartley-Whitaker et al., 2002; Schat et al., 2002). These studies also demonstrate that PCs play an important, probably essential, role in the detoxification of arsenite in As nonhyperaccumulating plants. The results from this study show that exposure to arsenate also induced the synthesis of $\mathrm{PC}_{2}$ in the roots and shoots of the As hyperaccumulator $P$. vittata. The concentration of $\mathrm{PC}_{2}$ was higher in the shoots than in the roots of $P$. vittata, which may be related to a higher concentration of As in the shoots than in the roots, and the predominance of arsenite in the shoots in this plant. However, $P$. vittata differs from As nonhyperaccumulators in two aspects. First, only $\mathrm{PC}_{2}$ was found in $P$. vittata, whereas other plant species investigated so far also contain PCs of longer chain length. Second, the concentrations of PCs in P. vittata determined in this study (up to $7 \mu \mathrm{mol} \mathrm{g}^{-1} \mathrm{~d}$. wt) are considerably lower than the values reported for Silene vulgaris (Sneller et al., 1999; Schat et al., 2002), Holcus lanatus (Hartley-Whitaker et al., 2001) and Rauvolfia serpentina cell cultures (Schmöger et al., 2000), under comparable concentrations of exposure to arsenate. In Experiment 3, $1000 \mu \mathrm{M}$ arsenate was found to inhibit root elongation by more than $50 \%$. However, the concentrations of $\mathrm{PC}_{2}$ in the $1000 \mu \mathrm{M}$ arsenate treatment were similar to those in the $500 \mu \mathrm{M}$ arsenate treatment, which did not inhibit root elongation. The results suggest that $P$. vittata has a rather limited capacity to accumulate PCs in response to As exposure.
In $R$. serpentia (Schmöger et al., 2000), S. vulgaris (Sneller et al., 1999; Schat et al., 2002) and in tolerant populations of H. lanatus (Hartley-Whitaker et al., 2002), the molar ratio of $\mathrm{PCs}-\mathrm{SH}$ to As is $\geq 3: 1$. This ratio is consistent with the structural model of one arsenite being coordinated with three thiol groups, which was observed in a reconstituted $\mathrm{As}-\mathrm{PC}_{2}$ complex using electrospray ionization mass spectroscopy (Schmöger et al., 2000). By contrast, we observed very low molar ratios of PCs-SH to As in the shoots (c. 0.09) and roots (c. 0.03 ) of $P$. vittata. These ratios imply that only a small proportion of the total As accumulated by the fern, c. 1\% and 3\% for roots and shoots, respectively, may be complexed with PCs, assuming a stoichiometry of three PCs-SH to one arsenite. These estimates are consistent with previous reports showing that inorganic arsenite was by far the most dominant species of As in the shoots of $P$. vittata (Francesconi et al., 2002; Wang et al., 2002). Furthermore, analysis using X-ray absorption spectroscopy showed that only a small proportion (c. 6\%) of As in the leaves of P. vittata was coordinated to $S$ (Webb et al., 2003). By contrast, almost all of the As in the shoots of Brassica juncea (Pickering et al., 2000) and Arabidopsis thaliana (Dhankher et al., 2002) was found to be complexed by thiols.

Schmöger et al. (2000) showed that an inhibition of GSH and PC synthesis by BSO led to an increased sensitivity of $R$. serpentia cell cultures to As toxicity. Even As-tolerant populations of $H$. lanatus, $S$. vulgaris and Agrostis castellana were rendered hypersensitive to As toxicity when BSO was added to the nutrient solutions (Hartley-Whitaker et al., 2002; Schat et al., 2002). In those studies, BSO alone had no toxic effect on root growth. In the present study, however, BSO $(0.5 \mathrm{~mm})$ alone was found to inhibit root growth of $P$. vittata markedly. Thus, it is difficult to judge whether a markedly decreased synthesis of GSH and PC as a result of the BSO treatment led to a higher sensitivity of $P$. vittata to As toxicity. The reason for the inhibitory effect of BSO on root growth of $P$. vittata remains unclear. One possible explanation is that a sufficient level of GSH is essential for root growth of $P$. vittata. An $A$. thaliana mutant ( $r m l 1$ ) that lacks the first enzyme of the GSH biosynthesis pathway exhibits defective root cell division, because GSH is required for the phase transition of the cell cycle (Vernoux et al., 2000). These authors also found that the addition of $2.5 \mathrm{~mm} \mathrm{BSO}$ to growth media completely inhibited root growth of wild type $A$. thaliana. Xiang et al. (2001) provided further evidence for a role of GSH in root growth. They showed that root growth in $A$. thaliana was decreased by $40 \%$ in the antisense plants with a low-level expression of $\gamma$-glutamylcysteine synthetase, compared with the wild type plants.

Because arsenite can be highly disruptive to metabolic processes in cytoplasm, it has to be detoxified. This may be achieved by complexation and/or vacuolar sequestration (Ghosh et al., 1999). In the leaves of P. vittata, As appears to be localized mainly in the vacuoles of epidermal cells (Lombi 
et al., 2002). Vacuolar sequestration is likely to be the main mechanism of As detoxification in this hyperaccumulator. Furthermore, the results from this study and other recent reports (Francesconi et al., 2002; Lombi et al., 2002; Wang et al., 2002; Webb et al., 2003) suggest that the bulk of the As that is sequestrated in the vacuoles is present as uncomplexed arsenite. What then is the role of PCs in the detoxification of As in P. vittata, considering the positive induction of PC synthesis by As exposure? It is possible that any arsenite present in the cytoplasm is complexed by PCs, thus preventing toxic effects. Cytosolic arsenite would only account for a small proportion of the total As accumulated by this species. It is not known whether PCs-As complexes, formed in the cytoplasm, are transported across tonoplast to the vacuoles. If so, PCs-As would have to dissociate in the vacuoles and PCs or their breakdown products efflux out of the vacuoles rapidly, to account for the large accumulation of As and the overall small ratios of $\mathrm{PCs}-\mathrm{SH}$ to As observed. This scenario is not very likely, considering that PCs-arsenite complexes should be more stable in the vacuoles ( $\mathrm{pH} c .5 .5)$ than in the cytoplasm $(\mathrm{pH} c .7 .5)$.

In conclusion, this study shows that, although arsenate exposure induces PC synthesis in P. vittata, the role of PCs in the detoxification of As appears to be limited. An analogy to our conclusion here is that PCs are not responsible for $\mathrm{Cd}$ hypertolerance in the hyperaccumulator Thlaspi caerulescens (Ebbs et al., 2002; Schat et al., 2002).

\section{Acknowledgements}

We thank Miss Sarah Dunham and Mr Adrian Crosland for technical assistance. J. Wang thanks the China Fellowship Council for a one-year fellowship. Rothamsted Research receives grant-aided support from the Biotechnology and Biological Sciences Research Council of the United Kingdom.

\section{References}

Asher CJ, Reay PF. 1979. Arsenic uptake by barley seedlings. Australian Journal of Plant Physiology 6: 459-466.

Dhankher OP, Li Y, Rosen BP, Shi J, Salt D, Senecoff JF, Sashti NA, Meagher RB. 2002. Engineering tolerance and hyperaccumulation of arsenic in plants by combining arsenate reductase and - glutamylcysteine synthetase expression. Nature Biotechnology 20: 1140-1145.

Ebbs S, Lau I, Ahner B, Kochian L. 2002. Phytochelatin synthesis is not responsible for $\mathrm{Cd}$ tolerance in the $\mathrm{Zn} / \mathrm{Cd}$ hyperaccumulator Thlaspi caerulescenes (J. \& C. Presl). Planta 214: 635-640.

Francesconi K, Visoottiviseth P, Sridokchan W, Goessler W. 2002. Arsenic species in an arsenic hyperaccumulating fern, Pityrogramma calomelanos: a potential phytoremediator of arsenic-contaminated soils. Science of the Total Environment 284: 27-35.

Ghosh M, Shen J, Rosen BP. 1999. Pathways of As(III) detoxification in Saccharomyces cerevisiae. Proceedings of the National Academy of Sciences, USA 96: 5001-5006.

Gladysheva TB, Oden KL, Rosen BP. 1994. Properties of the arsenate reductase of plasmid R773. Biochemistry 33: 7288-7293.

Glaubig RA, Goldberg S. 1988. Determination of inorganic arsenic (III) and arsenic (III plus V) using automated hydride-generation atomic-absorption spectrometry. Soil Science Society of America Journal 52: 536-537.

Grill E, Winnacker EL, Zenk MH. 1987. Phytochelatins, a class of heavy-metal-binding peptides from plants, are functionally analogous to metallothioneins. Proceedings of the National Academy of Sciences, USA 84: 439-443.

Ha SB, Smith AP, Howden R, Dietrich WM, Bugg S, O'Connell MJ, Goldsbrough PB, Cobbett CS. 1999. Phytochelatin synthase genes from arabidopsis and the yeast Schizosaccharomyces pombe. Plant Cell 11: $1153-1163$

Hartley-Whitaker J, Ainsworth G, Vooijs R, Ten Bookum W, Schat H, Meharg AA. 2001. Phytochelatins are involved in differential arsenate tolerance in Holcus lanatus. Plant Physiology 126: 299-306.

Hartley-Whitaker J, Woods C, Meharg AA. 2002. Is differential phytochelatin production related to decreased arsenate influx in arsenate tolerant Holcus lanatus? New Phytologist 155: 219-225.

Hewitt EJ. 1966. Sand and water culture methods used in the study of plant nutrition, 2nd edn. Farnham Royal, UK: Commonwealth Agricultural Bureaux.

Kabata-Pendias A, Pendias H. 1992. Trace elements in soils and plants, 2nd $e d n$. Boca Raton, FL, USA: CRC Press.

Lombi E, Zhao FJ, Fuhrmann M, Ma LQ, McGrath SP. 2002. Arsenic distribution and speciation in the fronds of the hyperaccumulator Pteris vittata. New Phytologist 156: 195-203.

Ma LQ, Komar KM, Tu C, Zhang WH, Cai Y, Kennelley ED. 2001. A fern that hyperaccumulates arsenic. Nature 409: 579-579.

Maitani T, Kubota H, Sato K, Yamada T. 1996. The composition of metals bound to class III metallothionein (phytochelatin and its desglycyl peptide) induced by various metals in root cultures of Rubia tinctorum. Plant Physiology 110: 1145-1150.

Meharg AA, Hartley-Whitaker J. 2002. Arsenic uptake and metabolism in arsenic resistant and nonresistant plant species. New Phytologist 154: $29-43$.

Meharg AA, Macnair MR. 1991. The mechanisms of arsenate tolerance in Deschampsia cespitosa (L.) Beauv and Agrostis capillaris L. New Phytologist 119: 291-297.

Meharg AA, Macnair MR. 1992. Suppression of the high-affinity phosphate uptake system: a mechanism of arsenate tolerance in Holcus lanatus $\mathrm{L}$. Journal of Experimental Botany 43: 519-524.

Mukhopadhyay R, Shi J, Rosen BP. 2000. Purification and characterization of Acr2p, the Saccharomyces cerevisiae arsenate reductase. Journal of Biological Chemistry 275: 21149-21157.

Pickering IJ, Prince RC, George MJ, Smith RD, George GN, Salt DE. 2000. Reduction and coordination of arsenic in Indian mustard. Plant Physiology 122: 1171-1177.

Schat H, Llugany M, Vooijs R, Hartley-Whitaker J, Bleeker PM. 2002. The role of phytochelatins in constitutive and adaptive heavy metal tolerances in hyperaccumulator and non-hyperaccumulator metallophytes. Journal of Experimental Botany 53: 2381-2392.

Schat H, Ten Bookum WM. 1992. Genetic control of copper tolerance in Silene vulgaris. Heredity 68: 219-229.

Schmöger MEV, Oven M, Grill E. 2000. Detoxification of arsenic by phytochelatins in plants. Plant Physiology 122: 793-801.

Sneller FEC, van Heerwaarden LM, Koevoets PLM, Vooijs R, Schat H, Verkleij JAC. 2000. Derivatization of phytochelatins from Silene vulgaris, induced upon exposure to arsenate and cadmium: Comparison of derivatization with Ellman's reagent and monobromobimane. Journal of Agricultural and Food Chemistry 48: 4014-4019.

Sneller FEC, Van Heerwaarden LM, Kraaijeveld-Smit FJL, Ten Bookum WM, Koevoets PLM, Schat H, Verkleij JAC. 1999. Toxicity of arsenate in Silene vulgaris, accumulation and degradation of arsenate-induced phytochelatins. New Phytologist 144: 223-232.

Tu C, Ma LQ. 2002. Effects of arsenic concentrations and forms on arsenic uptake by the hyperaccumulator ladder brake. Journal of Environmental Quality 31: 641-647. 
Ullrich-Eberius CI, Sanz A, Novacky AJ. 1989. Evaluation of arsenateand vanadate-associated changes of electrical membrane potential and phosphate transport in Lemna gibba-G1. Journal of Experimental Botany 40: $119-128$.

Vernoux T, Wilson RC, Seeley KA, Reichheld JP, Muroy S, Brown S, Maughan SC, Cobbett CS, Van Montagu M, Inze D, May MJ, Sung ZR. 2000. The root meristemless $1 /$ cadmium sensitive 2 gene defines a glutathione-dependent pathway involved in initiation and maintenance of cell division during postembryonic root development. Plant Cell 12: 97-109.

Visoottiviseth P, Francesconi K, Sridokchan W. 2002. The potential of Thai indigenous plant species for the phytoremediation of arsenic contaminated land. Environmental Pollution 118: 453-461.
Wang J, Zhao FJ, Meharg AA, Raab A, Feldmann J, McGrath SP. 2002. Mechanisms of arsenic hyperaccumulation in Pteris vittata. Uptake kinetics, interactions with phosphate, and arsenic speciation. Plant Physiology 130: 1552-1561.

Webb SM, Gaillard JF, Ma LQ, Tu C. 2003. XAS speciation of arsenic in a hyper-accumulating fern. Environmental Science and Technology 37: $754-760$.

Xiang CB, Werner BL, Christensen EM, Oliver DJ. 2001. The biological functions of glutathione revisited in Arabidopsis transgenic plants with altered glutathione levels. Plant Physiology 126: $564-574$.

Zhao FJ, Dunham SJ, McGrath SP. 2002. Arsenic hyperaccumulation by different fern species. New Phytologist 156: 27-31.

\section{About New Phytologist}

- New Phytologist is owned by a non-profit-making charitable trust dedicated to the promotion of plant science. Regular papers, Letters, Research reviews, Rapid reports and Methods papers are encouraged. Complete information is available at www.newphytologist.org

- All the following are free - essential colour costs, 25 offprints as well as a PDF (i.e. an electronic version) for each article, online summaries and ToC alerts (go to the website and click on 'Journal online')

- You can take out a personal subscription to the journal for a fraction of the institutional price. Rates start at $£ 86$ in Europe/\$145 in the USA \& Canada for the online edition (go to the website and click on 'Subscribe')

- If you have any questions, do get in touch with Central Office (newphytol@lancaster.ac.uk; tel +44 1524 592918) or, for a local contact in North America, the USA Office (newphytol@ornl.gov; tel 865576 5261) 